\title{
Mitochondrial nicotinamide adenine dinucleotide hydride dehydrogenase (NADH) subunit 4 (MTND4) polymorphisms and their association with male infertility
}

\author{
Fatina W. Dahadhah ${ }^{1}$ (D) Mayyas Saleh Jaweesh ${ }^{1} \cdot$ Mazhar Salim Al Zoubi $^{2}$ (D) Manal Issam Abu Alarjah ${ }^{2}$. \\ Mohamad Eid Hammadeh ${ }^{1}$ (D) Houda Amor ${ }^{1}$ (D)
}

Received: 9 November 2020 / Accepted: 18 April 2021 / Published online: 24 April 2021

(C) The Author(s) 2021

\begin{abstract}
Purpose The purpose of the present study was to determine the relationship between infertility and the polymorphisms of mitochondrial NADH dehydrogenase subunit 4 (MTND4) by spermatozoa analysis in fertile and subfertile men.

Methods Samples were divided into 68 subfertile men (case group) and 44 fertile men (control group). After semen analysis, samples were purified. The whole genome was extracted using a QIAamp DNA Mini Kit and the mitochondrial DNA was amplified by using the REPLI-g Mitochondrial DNA Kit. Polymerase chain reaction (PCR) was used to amplify the MT-ND4 gene. Then, samples were purified and sequenced using the Sanger method.

Results Twenty-five single-nucleotide polymorphisms (SNPs) were identified in the MTND4 gene. The genotype frequencies of the study population showed a statistically significant association between rs $2853495 \mathrm{G}>\mathrm{A}$ (Gly320Gly) and male infertility $(P=$ 0.0351). Similarly, the allele frequency test showed that rs $2853495 \mathrm{G}>\mathrm{A}$ (Gly320Gly) and rs869096886 A $>\mathrm{G}$ (Leu164Leu) were significantly associated with male infertility (adjusted $\mathrm{OR}=2.616,95 \% \mathrm{CI}=1.374-4.983, P=0.002$; adjusted $\mathrm{OR}=2.237,95 \%$ $\mathrm{CI}=1.245-4.017, P=0.007$, respectively).

Conclusion In conclusion, our findings suggested that male infertility was correlated with rs2853495 and rs869096886 SNPs in MTND4.
\end{abstract}

Keywords mtDNA $\cdot$ MTND4 $\cdot$ SNP $\cdot$ Male infertility

\section{Introduction}

Infertility, the inability to conceive after 12 months of unprotected sexual intercourse, affects $2.5-15 \%$ of couples in the world [1]. Approximately $50 \%$ of infertility cases are caused by male factors [2]. Sperm motility is an essential process for sperm movement to the fertilization site and normal fertilization which demand energy produced by sperm mitochondria [3]. Mitochondrial genes play an important role in the mature sperm construction and flagella movement after ejaculation [4].

Fatina W. Dahadhah

fwdhadha11@outlook.com

1 Department of Obstetrics \& Gynaecology, Saarland University, Homburg, Saar, Germany

2 Department of Basic Medical Sciences, Faculty of Medicine, Yarmouk University, Irbid 21163, Jordan
Moreover, mitochondria, the powerhouse of the cell [5], have their own genome that encodes 13 proteins [6]. The human mitochondrial genome is considerably compact and circular consisting of $16,569 \mathrm{bp}$. The rate of mutations in the mitochondrial DNA (mtDNA) is high due to the lack of histones and DNA repair mechanisms [7]. Therefore, mutations that occur in the mitochondrial genome play a major role in some human genetic disorders [8]. It has been reported that mutations in the mtDNA are associated with certain types of male infertility. For instance, mutations in the mtDNA polymerase (POLG) locus were associated with male infertility [9]. In another study, a high incidence of single-nucleotide polymorphisms (SNPs) in mtDNA was observed in semen samples of poor sperm quality [10]. Moreover, several studies have shown that mtDNA mutations in sperm can lead to reduced sperm motility and eventually to male infertility [10-12]. However, mtDNA mutations especially reduce sperm motility without significantly compromising the fertility of young males [13]. 
Oxidative phosphorylation (OXPHOS) is an effective way to release energy; however, it also generates reactive oxygen species (ROS) during mitochondrial activity. Large amounts of ROS are detrimental to cells [14]. The generation of reactive oxygen species occurs as a natural physiological process in sperm. However, a small amount of ROS is actually required for normal sperm functioning. ROS such as nitric oxide (NO) and superoxide anion play an important role in the capacitation and the acrosome reaction. Moreover, ROS are involved in sperm-oocyte communication, but disproportionate levels of ROS production can negatively impact the spermatozoa quality and impair their fertilization capacity [15].

Several studies showed a strong correlation between impaired mtDNA and the occurrence of male infertility conditions such as asthenozoospermia, oligozoospermia, and teratozoospermia. For instance, large-scale deletions in the mtDNA have been identified in asthenozoospermia in various populations [16-18], while other studies established an association between CAG repeats and the development of oligozoospermia and teratozoospermia in infertile males [19].

Moreover, the removal of certain structural genes and tRNA genes may result in a large number of mtDNA deletions. Sperm containing defective mitochondria cannot effectively produce adenosine triphosphate (ATP) and are more likely to produce ROS and free radicals, thereby causing defects in mtDNA, producing less energy, and leading to deficits in motility and fertility $[11,20]$.

Genetic disorders are responsible for about $15-30 \%$ of male factor infertility. The proper understanding of the genetic basis of reproductive problems is requisite to managing the treatment of an infertile couple [21, 22]. Genetic disorders involving male infertility may be caused by chromosomal abnormalities, autosomal gene defects, or $\mathrm{Y}$ chromosome mutations.

The karyotype variant of Klinefelter's syndrome, $47, \mathrm{XXY}$, is the most common numerical chromosomal abnormality associated with male infertility and occurs in 1 in 500 newborn males $[23,24]$. Eleven percent of azoospermic and $0.7 \%$ of oligozoospermic males are probable to have this condition [24].

The human Y chromosome has also been found to be responsible for male infertility. Y-linked mutations have the greatest impact on spermatogenesis [23, 25]. Y-chromosome microdeletions have been reported in patients with suboptimal semen quality $(7.4 \%)$ [26].

Sperms with defective mitochondria cannot effectively produce the required ATP and are more likely to produce free radicals/reactive oxygen species, causing genotoxicity and reduced sperm motility which can lead to male infertility [11, 20]. On the other hand, the mitochondrial respiratory chain consists of 13 proteins which are a constitutional part of membrane complexes. In particular, complex I includes seven nicotinamide adenine dinucleotide hydride (NADH) dehydrogenase subunits (ND1,ND2,ND3, ND4, ND4L, $N D 5$, and ND6). In comparison, complex III contains cytochrome B, complex IV contains three subunits: cytochrome oxidase subunit I (COX-I), cytochrome oxidase subunit II (COX-II), and cytochrome oxidase subunit III (COX-III), and complex V contains ATPase 6 and ATPase 8 [27]. Complex I, the first enzyme of the electron transport chain, oxidizes NADH which is generated through the Krebs cycle in the matrix of mitochondria. Therefore, complex I is the main entry point for electrons to the respiratory chain and is suggested as the rate-limiting step in overall respiration [28].

MTND4 gene spans from 10,760 to 12,137 in the human mtDNA genome (National Centre of Biotechnology Information; NCBI). MTND4 is one of the core mitochondrial-encoded subunits of the mitochondrial membrane respiratory chain NADH dehydrogenase (Complex I) [29, 30]. MTND4 gene codes for the NADH-ubiquinone oxidoreductase chain 4 (ND4) protein [31]. The ND4 protein is located in the mitochondrial inner membrane and is the largest of the five complexes of the electron transport chain [32]. MTND4 plays an important role in the oxidative phosphorylation process and it has been reported to be associated with sperm motility $[10,11,33]$. Various studies have shown a significant association of polymorphisms in MTND4 with age-related muscular degeneration (AMD), Leber's hereditary optic neuropathy (LHON), mesial temporal lobe epilepsy (MTLE), and cystic fibrosis [31], [34-36]. However, the overall association between MTND4 polymorphisms and male infertility remains unknown.

Accordingly, we aimed to examine whether MTND4 polymorphisms contribute to male infertility. We first identified SNPs in the MTND4 gene by Sanger sequencing and then determined their association with infertility using a casecontrol study design.

\section{Materials and methods}

\section{Sperm sample collection}

One hundred and twelve semen samples were collected from subfertile and fertile males attending the in vitro fertilization clinic. The informed consent of all individuals was obtained before collecting samples. The study population aged between 26 and 48 years had been divided into two groups according to semen analysis results [37] to 68 subfertile and 44 fertile males. The individuals with age over 50 years old, men exposed to chemotherapy or radiotherapy, varicocele or any surgical procedure in the reproductive tract, diabetes, blood pressure and any chronic disease, hormonal imbalance, or Y chromosome microdeletion were excluded from this study. 


\section{Mitochondrial DNA extraction}

Before DNA extraction, semen samples were purified by discontinuous pure sperm gradient (45\% and 90\%) technique (Nidacon International, Sweden). Briefly, semen samples were loaded at the upper level of the gradient and centrifuged at $250 \mathrm{~g}$ for $20 \mathrm{~min}$. Thereafter, the pellet was collected and washed twice with a sperm washing medium. The absence of all other cells was confirmed by microscopic examination.

The whole genome was extracted from the spermatozoa using a QIAamp DNA Mini Kit; then, the mitochondrial DNA was amplified by using the REPLI-g Mitochondrial DNA Kit (QIAGEN, Hilden, Germany), as recommended by the kit instruction manual. Isolated DNA with an optimal density ratio of $260 / 280$ of 1.8 or more was chosen for further analysis and stored at $-80^{\circ} \mathrm{C}$.

\section{Polymerase chain reaction}

The polymerase chain reaction was applied to determine the gene variant by using self-designed pairs of specific primers using PRIME 3 software for the target gene (MTND4) (Nd4.F 5'-CTACGTACATAACCTAAACC-3', Nd4.R 5'-CTGA TGTTTTGGTTAAAC- $3^{\prime}\left(\mathrm{Tm}=49^{\circ} \mathrm{C}\right)$ ), where the amplicon size is $1432 \mathrm{bp}$. An additional internal primer Nd4.I: 5'-CTTA AAACTAGGCGGCTATGG-3' was designed for sequencing. The primers were based on the human mitochondrial sequence; accession number NC_012920, provided by the National Centre of Biotechnology Information and ordered from Microsynth seq lab-Germany.

The amplification reaction was carried out in a $30 \mu \mathrm{L}$ mixture using ThermoScientific Dream Taq Green PCR master mix $(2 \times)$, according to manufacturer instructions. To confirm the presence of an amplified PCR product, $5 \mu \mathrm{L}$ of each PCR sample was investigated by $1 \%$ agarose gel electrophoresis using $1 \times$ TBE buffer and a DNA ladder (1 kb) (NE Biolabs, USA) as a reference. Electrophoresis was carried out at $100 \mathrm{~V}$ for $45 \mathrm{~min}$. Gels were stained with red-safe stain and then DNA was visualized by ultra-violet (UV) transilluminator with Image LabTM Software (BIO-RAD, USA) (Fig. 1).

\section{DNA sequencing}

Samples were purified and sequenced by the Sanger method at Microsynth Seq lab in Germany. The SNPs of MTND4 were detected by sequence analysis based on the reference sequence of human MT (GenBank accession number: NC 012920). The sequenced DNA samples were analyzed using Mutation Surveyor software to determine the mt-DNA variants.

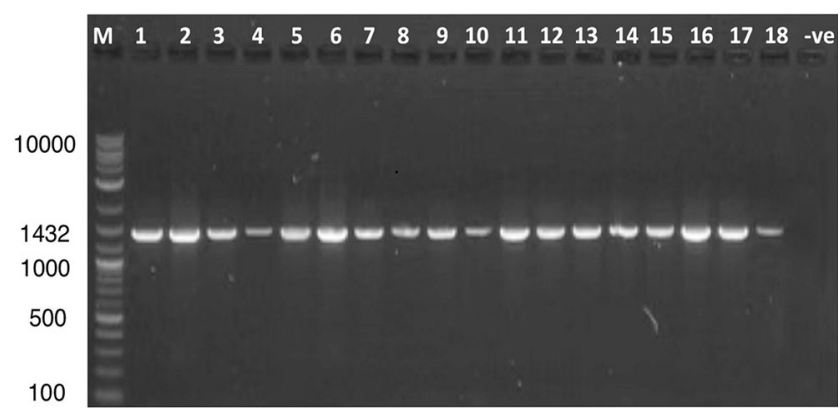

Fig. 1 Representative gel electrophoresis on $1 \%$ agarose gel of PCR products for the amplification of the MTND4 gene (1432 Bp). Lane M: DNA ladder (100-10,000 bp) (NE Biolabs, USA), lanes 1-18: PCR sample products, lane -ve: negative control. Electrophoresis was carried out at $100 \mathrm{~V}$ for $45 \mathrm{~min}$. Gels were stained with red-safe stain and then DNA was visualized by ultra-violet (UV) transilluminator using Image LabTM Software (BIO-RAD, USA)

\section{Statistical analyses}

Genotypes and allele frequencies between the subfertile (case) and fertile (control) groups were performed using the chi-square test and Fischer's exact test, respectively. The identified SNPs were also tested for the HardyWeinberg equilibrium test to determine the genotype frequencies and to describe statistically significant deviations from the equilibrium. The allele frequencies between the subfertile (case) and fertile (control) groups were measured according to odds ratios (ORs) and 95\% confidence intervals (CIs). $P$ value was considered statistically significant if $\leq 0.05$. Statistical analyses were performed using the SPSS Version 22 for Mac.

\section{Results}

In this study, males who had one child or more and had normal semen parameters [volume: $1.5 \mathrm{ml}$, sperm count: 15 million spermatozoa/ml; normal forms: 4\%; vitality: 58\% live; progressive motility: $32 \%$; total (progressive + nonprogressive) motility: $40 \%$, according to WHO guideline 2010] were considered as the fertile group, and those who failed to have children after 12 months or more of regular unprotected sexual intercourse and had one sperm parameters under WHO (2010) criteria were considered as the sub-fertile group. Thus, subjects were divided into two groups: a control group (fertile, $n$ $=44$ ) and a case group (subfertile, $n=68$ ).

The study population did not show any significant difference between the ages of the subfertile and fertile group $(P=0.247)$. On the other hand, the semen analysis showed significant differences in the mean percentage of sperm concentration, total motility, and morphologically normal spermatozoa between the fertile and subfertile individuals $(P<0.0001)$ (Table 1$)$. 
Table 1 Comparison of the semen analysis parameters between the fertile and subfertile groups

\begin{tabular}{llll}
\hline Parameter & $\begin{array}{l}\text { Fertile }(n=44) \\
\text { Median (range) }\end{array}$ & $\begin{array}{l}\text { Subfertile }(n=68) \\
\text { Median (range) }\end{array}$ & $P$ value \\
\hline Age & $34(26-48)$ & $34(26-48)$ & 0.247 \\
Sperm concentration $(106 \times 1 \mathrm{ml})$ & $78.5(17-185)$ & $28(0.6-135)$ & $<0.0001$ \\
Total motility (PR + NP\%) & $67.5(44-90)$ & $48.5(2-88)$ & $<0.0001$ \\
Morphologically normal spermatozoa $(\%)$ & $24.5(20-30)$ & $15(0-28)$ & $<0.0001$ \\
\hline
\end{tabular}

\section{Genotypes and allelic frequencies}

A total of twenty-five SNPs in MTND4 in the case and control groups were detected: rs2853495, rs2857284, rs2853496, rs2853497, rs3087901, rs2853493, rs2853490, rs3088053, rs2853491, rs2857285, rs28358282, rs28594904, rs28669780, rs28415973, rs28471078, rs55714831, rs28358283, rs75214962, rs28529320, rs2853494, rs28609979, rs28358286, rs28359168, rs28384199, and rs869096886 (Table 2).

To determine whether the variations of MTND4 were related to infertility, we compared each of the genotypes and allele frequencies between the case and control groups. For the rs2853495, the mutant allele was higher than the wild-type allele frequency $(P=0.002)$ (Table 3$)$ and the number of homozygous mutant types (AA) was higher than the homozygous wild type $(\mathrm{GG})(P=0.0351)$. Furthermore, the wild-type allele frequency in rs869096886 was significantly higher than the mutant allele frequency $(P=0.007)$. The remaining SNPs showed no significant difference in allele and genotype distribution among fertile and subfertile groups. Moreover, all SNPs were tested for the Hardy-Weinberg genotype frequency test. All of these SNPs showed a significant deviation from HWE $(P<0.0001)$.

\section{Discussion}

Sperm mitochondrial DNA contains no introns and lacks the protection of histones or DNA binding proteins. Therefore, it replicates rapidly without DNA repair mechanisms [6]. Consequently, mitochondrial mutation rates are higher by about 10-100 times than nuclear DNA. Mutations that occur in the mitochondrial genome play a major role in some human genetic disorders [8].

The purpose of the current study was to investigate whether polymorphisms in the MTND4 gene are correlated with male infertility. Several studies have reported that among the identified MTND4 SNPs, rs2853495 is related to ulcerative colitis and pancreatic cancer [38, 39], and rs869096886 is related to schizophrenia [40], whereas rs2857285 is associated with a more invasive form of ovarian cancer [41]. Moreover, rs28384199 is related to late-onset encephalopathy and is considered a highly pathogenic mutation [42].

Additionally, many males with ulcerative colitis, a principal form of inflammatory bowel disease, are unable to control their smoking, drinking, and eating habits, which can contribute to sexual dysfunction and infertility [43]. Moreover, it has been repeatedly reported that the fertility of schizophrenia patients is lower than that of people with other psychiatric illnesses and the general population [44].

In the present study, we scanned the polymorphisms of subfertile and fertile males by direct sequencing of the MTND4 gene, and identified twenty-five SNPs as follows: rs2853495, rs2857284, rs2853496, rs2853497, rs3087901, rs2853493, rs2853490, rs3088053, rs2853491, rs2857285, rs28358282, rs28594904, rs28669780, rs28415973, rs28471078, rs55714831, rs28358283, rs75214962, rs28529320, rs2853494, rs28609979, rs28358286, rs28359168, rs28384199, and rs869096886. The rs28594904 (Ser86Asn or Ser86Thr), rs28669780 (Leu282Met), and rs28384199 (Arg340Ser or Arg340Gly) SNPs are missense variants, whereas the rest of SNPs are synonymous coding variants. All SNPs were also tested for the Hardy-Weinberg genotype frequency test (HWE). All of the SNPs showed a significant deviation from HWE $(P<0.0001)$ which means that the genotype distribution was not following HardyWeinberg and biased to one group.

Overall, in the genotype frequency test, we found a significant association between the SNP rs2853495 and male infertility. In the allele frequency test, rs2853495 (G11719A) and rs869096886 (A11251G) were also associated with male infertility, indicating that the presence of the allele itself may be associated with male infertility regardless of its genotype.

Moreover, the OR of rs2853495 SNP was associated with a 2.61 times increased risk of subfertile males than fertile ones. Furthermore, the OR of rs 869096886 (2.237) was also higher for subfertile males than for control. These results demonstrated that although the rs2853495 and the rs869096886 SNPs are synonymous variants and do not cause an amino acid change, they can be related to male infertility. Nevertheless, synonymous variants have been suggested to play a role in gene regulation and possibly the development of 
Table 2 Genotype frequency of MTND4 polymorphisms between subfertile and fertile groups

\begin{tabular}{|c|c|c|c|c|c|c|}
\hline SNP & Contig position & Protein position & Genotype & Subfertile $(N)$ & Fertile $(N)$ & $P$ value \\
\hline rs2853495 & \multirow[t]{3}{*}{11719} & \multirow[t]{3}{*}{ Gly320Gly } & GG & 25 & 8 & \multirow[t]{3}{*}{0.0351} \\
\hline \multirow{2}{*}{$\mathrm{G}>\mathrm{A}$} & & & GA & 0 & 0 & \\
\hline & & & AA & 43 & 36 & \\
\hline rs 2857284 & \multirow[t]{3}{*}{10873} & \multirow[t]{3}{*}{ Pro38Pro } & TT & 49 & 35 & \multirow[t]{3}{*}{0.0995} \\
\hline \multirow[t]{2}{*}{$\mathrm{T}>\mathrm{C}$} & & & $\mathrm{TC}$ & 2 & 4 & \\
\hline & & & $\mathrm{CC}$ & 17 & 5 & \\
\hline rs2853496 & \multirow[t]{4}{*}{11914} & \multirow[t]{4}{*}{ Thr385Thr } & GG & 56 & 40 & \multirow[t]{4}{*}{0.597} \\
\hline $\mathrm{G}>\mathrm{A}, \mathrm{C}$ & & & GA & 3 & 1 & \\
\hline & & & $\mathrm{AC}$ & 1 & 0 & \\
\hline & & & AA & 8 & 3 & \\
\hline rs2853497 & 12007 & .Trp416.Trp & GG & 63 & 39 & 0.598 \\
\hline $\mathrm{G}>\mathrm{A}$ & & & GA & 3 & 4 & \\
\hline & & & AA & 2 & 1 & \\
\hline rs3087901 & 11944 & Leu395Leu & TT & 63 & 42 & 0.548 \\
\hline $\mathrm{T}>\mathrm{A}, \mathrm{C}, \mathrm{G}$ & & & $\mathrm{TC}$ & 0 & 0 & \\
\hline & & & $\mathrm{CC}$ & 5 & 2 & \\
\hline rs2853493 & 11467 & Leu236Leu & AA & 66 & 40 & 0.158 \\
\hline $\mathrm{A}>\mathrm{G}$ & & & AG & 0 & 0 & \\
\hline & & & GG & 2 & 4 & \\
\hline rs2853490 & 11176 & Gln139Gln & GG & 66 & 40 & 0.183 \\
\hline $\mathrm{G}>\mathrm{A}$ & & & GA & 0 & 2 & \\
\hline & & & AA & 2 & 2 & \\
\hline rs3088053 & 11812 & Leu351Leu & AA & 64 & 42 & 0.758 \\
\hline $\mathrm{A}>\mathrm{C}, \mathrm{G}$ & & & AG & 0 & 0 & \\
\hline & & & GG & 4 & 2 & \\
\hline rs2853491 & 11335 & Asn192Asn & $\mathrm{CC}$ & 66 & 42 & 0.655 \\
\hline $\mathrm{C}>\mathrm{T}$ & & & $\mathrm{CT}$ & 0 & 0 & \\
\hline & & & TT & 2 & 2 & \\
\hline rs 2857285 & 10915 & Cys52Cys & TT & 66 & 43 & 0.241 \\
\hline $\mathrm{T}>\mathrm{C}, \mathrm{G}$ & & & $\mathrm{TC}$ & 0 & 1 & \\
\hline & & & $\mathrm{CC}$ & 2 & 0 & \\
\hline rs28358282 & 10810 & Leu17Leu & TT & 67 & 42 & 0.434 \\
\hline $\mathrm{T}>\mathrm{C}$ & & & $\mathrm{TC}$ & 1 & 1 & \\
\hline & & & $\mathrm{CC}$ & 0 & 1 & \\
\hline rs28594904 & 11016 & Ser86Asn & GG & 67 & 42 & 0.434 \\
\hline $\mathrm{G}>\mathrm{A}, \mathrm{C}$ & & Ser86Thr & GA & 0 & 1 & \\
\hline & & & AA & 1 & 1 & \\
\hline rs28669780 & 11603 & Leu282Met & $\mathrm{CC}$ & 67 & 42 & 0.434 \\
\hline $\mathrm{C}>\mathrm{A}$ & & & $\mathrm{CA}$ & 0 & 1 & \\
\hline & & & AA & 1 & 1 & \\
\hline rs28415973 & 12091 & Ile444Ile & TT & 67 & 42 & 0.434 \\
\hline $\mathrm{T}>\mathrm{C}$ & & & $\mathrm{TC}$ & 0 & 1 & \\
\hline & & & $\mathrm{CC}$ & 1 & 1 & \\
\hline rs28471078 & 11722 & Leu321Leu & TT & 67 & 43 & 0.754 \\
\hline $\mathrm{T}>\mathrm{C}$ & & & $\mathrm{TC}$ & 0 & 0 & \\
\hline & & & $\mathrm{CC}$ & 1 & 1 & \\
\hline rs55714831 & 11332 & Ala191Ala & $\mathrm{CC}$ & 67 & 43 & 0.754 \\
\hline $\mathrm{C}>\mathrm{T}$ & & & $\mathrm{CT}$ & 1 & 1 & \\
\hline & & & TT & 0 & 0 & \\
\hline rs 28358283 & 10819 & Lys20Lys & AA & 67 & 44 & 0.419 \\
\hline $\mathrm{A}>\mathrm{G}$ & & & AG & 0 & 0 & \\
\hline & & & GG & 1 & 0 & \\
\hline rs75214962 & 11197 & Gly146Gly & $\mathrm{CC}$ & 67 & 44 & 0.419 \\
\hline $\mathrm{C}>\mathrm{T}$ & & & CT & 0 & 0 & \\
\hline & & & TT & 1 & 0 & \\
\hline rs 28529320 & 11485 & Gly242Gly & TT & 68 & 43 & 0.211 \\
\hline $\mathrm{T}>\mathrm{C}$ & & & $\mathrm{TC}$ & 0 & 0 & \\
\hline & & & $\mathrm{CC}$ & 0 & 1 & \\
\hline Rs2853494 & 11641 & Met294Met & AA & 68 & 43 & 0.211 \\
\hline$A>G$ & & & AG & 0 & 0 & \\
\hline & & & GG & 0 & 1 & \\
\hline rs28609979 & 11365 & Ala202Ala & TT & 68 & 44 & - \\
\hline $\mathrm{T}>\mathrm{C}$ & & & $\mathrm{TC}$ & 0 & 0 & \\
\hline & & & $\mathrm{CC}$ & 0 & 0 & \\
\hline rs28358286 & 11674 & Thr305Thr & $\mathrm{CC}$ & 68 & 43 & 0.211 \\
\hline $\mathrm{C}>\mathrm{T}$ & & & $\mathrm{CT}$ & 0 & 0 & \\
\hline & & & $\mathrm{CC}$ & 0 & 1 & \\
\hline rs28359168 & 11947 & Thr396Thr & AA & 68 & 43 & 0.211 \\
\hline $\mathrm{A}>\mathrm{G}$ & & & AG & 0 & 0 & \\
\hline
\end{tabular}


Table 2 (continued)

\begin{tabular}{|c|c|c|c|c|c|c|}
\hline SNP & Contig position & Protein position & Genotype & Subfertile $(N)$ & Fertile $(N)$ & $P$ value \\
\hline & & & GG & 0 & 1 & \\
\hline rs28384199 & 11777 & Arg340Ser & $\mathrm{CC}$ & 67 & 44 & 0.419 \\
\hline \multirow{2}{*}{$\mathrm{C}>\mathrm{A}, \mathrm{G}$} & & Arg340Gly & $\mathrm{CG}$ & 0 & 0 & \\
\hline & & & GG & 1 & 0 & \\
\hline rs869096886 & 11251 & Leu164Leu & AA & 52 & 26 & 0.147 \\
\hline \multirow[t]{2}{*}{$A>G$} & & & AG & 1 & 1 & \\
\hline & & & GG & 15 & 17 & \\
\hline
\end{tabular}

SNP single-nucleotide polymorphism

The significant results are in bold

Table 3 Allele frequency of MTND4 polymorphisms between subfertile and fertile groups

\begin{tabular}{|c|c|c|c|c|c|c|c|}
\hline SNP & Contig position & Protein position & Allele & Subfertile $(N)$ & Fertile $(N)$ & OR $(95 \% \mathrm{CI})^{*}$ & $P$ value \\
\hline rs 2853495 & \multirow{2}{*}{11719} & \multirow{2}{*}{ Gly320Gly } & G & 50 & 16 & $2.616(1.374-4.983)$ & 0.002 \\
\hline $\mathrm{G}>\mathrm{A}$ & & & A & 86 & 72 & & \\
\hline rs2857284 & \multirow[t]{2}{*}{10873} & \multirow[t]{2}{*}{ Pro38Pro } & $\mathrm{T}$ & 100 & 74 & $0.5255(0.264-1.044)$ & 0.071 \\
\hline $\mathrm{T}>\mathrm{C}$ & & & $\mathrm{C}$ & 36 & 14 & & \\
\hline rs2853496 & \multirow[t]{2}{*}{11914} & \multirow[t]{2}{*}{ Thr385Thr } & $\mathrm{G}$ & 115 & 81 & $0.496(0.200-1.230)$ & 0.145 \\
\hline $\mathrm{G}>\mathrm{A}, \mathrm{C}$ & & & A & 20 & 7 & & \\
\hline rs2853497 & \multirow[t]{2}{*}{12007} & \multirow[t]{2}{*}{ Trp416Trp } & G & 129 & 82 & $1.348(0.437-4.155)$ & 0.771 \\
\hline $\mathrm{G}>\mathrm{A}$ & & & A & 7 & 6 & & \\
\hline rs3087901 & \multirow[t]{2}{*}{11944} & \multirow[t]{2}{*}{ Leu395Leu } & $\mathrm{T}$ & 126 & 84 & $0.6000(0.18-1.97)$ & 0.573 \\
\hline $\mathrm{T}>\mathrm{A}, \mathrm{C}, \mathrm{G}$ & & & $\mathrm{C}$ & 10 & 4 & & \\
\hline rs2853493 & \multirow[t]{2}{*}{11467} & \multirow[t]{2}{*}{ Leu236Leu } & A & 132 & 80 & $3.300(0.962-11.31)$ & 0.066 \\
\hline $\mathrm{A}>\mathrm{G}$ & & & G & 4 & 8 & & \\
\hline rs2853490 & \multirow{2}{*}{11176} & \multirow[t]{2}{*}{ Gln139Gln } & $\mathrm{G}$ & 132 & 82 & $2.415(0.661-8.817)$ & 0.196 \\
\hline $\mathrm{G}>\mathrm{A}$ & & & A & 4 & 6 & & \\
\hline rs3088053 & \multirow[t]{2}{*}{11812} & \multirow[t]{2}{*}{ Leu351Leu } & A & 128 & 84 & $0.761(0.222-2.611)$ & 0.768 \\
\hline $\mathrm{A}>\mathrm{C}, \mathrm{G}$ & & & $\mathrm{G}$ & 8 & 4 & & \\
\hline rs2853491 & \multirow{2}{*}{11335} & \multirow{2}{*}{ Asn192Asn } & $\mathrm{C}$ & 132 & 84 & $1.571(0.382-6.456)$ & 0.714 \\
\hline & & & $\mathrm{T}$ & 4 & 4 & & \\
\hline rs2857285 T>C,G & 10915 & Cys52Cys & $\mathrm{T}$ & 132 & 87 & $0.379(0.041-3.453)$ & 0.650 \\
\hline rs $28358282 \mathrm{~T}>\mathrm{C}$ & 10810 & Leu17Leu & $\mathrm{T}$ & 135 & 85 & $4.765(0.487-46.58)$ & 0.302 \\
\hline rs28594904 G>A,C & \multirow[t]{2}{*}{11016} & & $\begin{array}{l}\mathrm{C} \\
\mathrm{G}\end{array}$ & 134 & 85 & $2.365(0.386-14.45)$ & 0.383 \\
\hline & & Ser86Thr & A & 2 & 3 & & \\
\hline rs28669780 C>A & 11603 & Leu282Met & $\mathrm{C}$ & 134 & 85 & $2.365(0.386-14.45)$ & 0.383 \\
\hline $\begin{array}{l}\text { rs } 28415973 \\
T>C\end{array}$ & 12091 & Ile444Ile & $\mathrm{T}$ & 134 & 85 & $2.365(0.386-14.45)$ & 0.383 \\
\hline $\begin{array}{l}\mathrm{T}>\mathrm{C} \\
\mathrm{rs} 28471078\end{array}$ & 11722 & Leu321Leu & $\begin{array}{l}\mathrm{C} \\
\mathrm{T}\end{array}$ & 134 & $\begin{array}{l}3 \\
86\end{array}$ & $1.558(0.215-11.27)$ & 0.646 \\
\hline $\mathrm{T}>\mathrm{C}$ & & & $\mathrm{C}$ & 2 & 2 & & \\
\hline rs55714831 C>T & 11332 & Ala191Ala & $\mathrm{C}$ & 135 & 87 & $1.552(0.095-25.15)$ & 1.000 \\
\hline rs28358283 A>G & 10819 & Lys20Lys & $\begin{array}{l}\mathrm{T} \\
\mathrm{A}\end{array}$ & $\begin{array}{l}1 \\
134\end{array}$ & $\begin{array}{l}1 \\
88\end{array}$ & $0.304(0.014-6.411)$ & 0.520 \\
\hline & & & G & 2 & 0 & & \\
\hline rs75214962 C>T & 11197 & Gly146Gly & $\mathrm{C}$ & 134 & 88 & $0.304(0.014-6.411)$ & 0.520 \\
\hline rs28529320 & 11485 & Gly242Gly & $\begin{array}{l}\mathrm{T} \\
\mathrm{T}\end{array}$ & $\begin{array}{l}2 \\
136\end{array}$ & $\begin{array}{l}0 \\
86\end{array}$ & $7890(037-166.44)$ & 0153 \\
\hline $\mathrm{T}>\mathrm{C}$ & & & $\mathrm{C}$ & 0 & 2 & & \\
\hline rs2853494 & 11641 & Met294Met & A & 136 & 86 & $7.890(0.37-166.44)$ & 0.153 \\
\hline $\mathrm{A}>\mathrm{G}$ & & & $\mathrm{G}$ & 0 & 2 & & \\
\hline rs28609979 T>C & 11365 & Ala202Ala & $\mathrm{T}$ & 136 & 88 & - & - \\
\hline & & & $\mathrm{C}$ & 0 & 0 & & \\
\hline $\begin{array}{l}\text { rs } 28358286 \\
C>T\end{array}$ & 11674 & Thr305Thr & C & $\begin{array}{l}136 \\
0\end{array}$ & $\begin{array}{l}86 \\
2\end{array}$ & $7.890(0.37-166.44)$ & 0.153 \\
\hline rs28359168 & 11947 & Thr396Thr & $\mathrm{A}$ & 136 & 86 & $7.890(0.37-166.44)$ & 0.153 \\
\hline$A>G$ & & & G & 0 & 2 & & \\
\hline rs28384199 & 11777 & Arg340Ser & $\mathrm{C}$ & 134 & 88 & $0.304(0.01-6.41)$ & 0.520 \\
\hline $\mathrm{C}>\mathrm{A}, \mathrm{G}$ & & Arg340Gly & $\mathrm{G}$ & 2 & 0 & & \\
\hline rs869096886 A>G & 11251 & Leu164Leu & A & 105 & 53 & $2.237(1.24-4.01)$ & 0.007 \\
\hline & & & G & 31 & 35 & & \\
\hline
\end{tabular}

$S N P$ single-nucleotide polymorphism, $O R$ odds ratio, $C I$ confidence interval

The significant results are in bold 
diseases [45]. For instance, synonymous mutations have been reported to regulate gene expression through the miRNA [46]. In another example, a synonymous mutation was found to affect mRNA stability [47]. Therefore, these synonymous variants in the mtDNA need to be investigated by functional studies to reveal their possible role in sperm function and male infertility. Additionally, mtDNA methylation has been related to sperm quality which can be associated with the synonymous mutations [48]. The rs2853495 SNP is a synonymous variant, as the codon substitution from [GGG] to [GGA] at position 11719 does not change the encoded amino acid (glycine). Additionally, the rs869096886 is also a synonymous variant that is changed from [CTA] to [CTG] at position 11251. Therefore, the amino acid remains leucine which means that this change does not affect the resulting product's protein sequence (NCBI).

Additionally, the copy number variant (CNV) is proposed to play a role in the development of certain diseases such as autism [49]. However, CNV will be more powerful when it is combined with other SNPs. Variants of unknown significance (VOUS) are another area that can be further investigated to correlate certain diseases and disorders with the genetic makeup of certain individuals. Genetic markers require intensive functional studies to reveal the molecular role of specific variants in the development of disease.

Less is known about mitochondrial gene polymorphisms in male infertility. Therefore, we identified the genetic associations between mitochondrial polymorphisms and male infertility. Our study is the first to explore the association between MTND4 SNPs and male infertility. Although the sample size was small, our findings suggest that the rs2853495 and rs869096886 SNPs in MTND4 might be associated with male infertility. However, analysis of a larger sample is needed and will allow a better understanding and clarification of the role of these MTND4 SNPs in male infertility.

\section{Conclusion}

In conclusion, we identified an as yet unknown association between mitochondrial gene polymorphisms in MTND4 and male infertility. In the genotype frequency test, we found a significant association between the SNP rs2853495 and male infertility. In the allele frequency test, rs2853495 and rs869096886 were also associated with male infertility. This indicates that mitochondrial genetics might help to give a better understanding of the correlation between the presence of these SNPs and the male's infertility. Moreover, larger prospective studies are required to confirm these associations of mitochondrial gene polymorphisms and male infertility and to clarify the definite effect of the mitochondrial genetic variations in male infertility.

Supplementary Information The online version contains supplementary material available at https://doi.org/10.1007/s10815-021-02199-w.

Acknowledgements We would like to thank the the Department of Obstetrics, Gynaecology and Reproductive Medicine, University Hospital of Saarland, for their financial support. We thank Dr. Gregory Eaton/Rowan University-USA for his help in the proofreading of the manuscript.

Funding Open Access funding enabled and organized by Projekt DEAL. This work is funded by the Department of Obstetrics and Gynaecology, Saarland University, Germany

\section{Declarations}

Ethical approval Ethical approval for this study was obtained from the Institutional Ethics Committee of Saarland University. All the subjects provided written informed consent before participation in this research.

Conflict of interest The authors declare no competing interests.

Open Access This article is licensed under a Creative Commons Attribution 4.0 International License, which permits use, sharing, adaptation, distribution and reproduction in any medium or format, as long as you give appropriate credit to the original author(s) and the source, provide a link to the Creative Commons licence, and indicate if changes were made. The images or other third party material in this article are included in the article's Creative Commons licence, unless indicated otherwise in a credit line to the material. If material is not included in the article's Creative Commons licence and your intended use is not permitted by statutory regulation or exceeds the permitted use, you will need to obtain permission directly from the copyright holder. To view a copy of this licence, visit http://creativecommons.org/licenses/by/4.0/.

\section{References}

1. Agarwal A, Ahmad G, Sharma R. Reference values of reactive oxygen species in seminal ejaculates using chemiluminescence assay. J Assist Reprod Genet. 2015;32:1721-9. https://doi.org/10. 1007/s10815-015-0584-1.

2. Talebi E, Karimian M, Nikzad H. Association of sperm mitochondrial DNA deletions with male infertility in an Iranian population, Mitochondrial DNA Part A DNA Mapping. Seq Anal. 2018. https:// doi.org/10.1080/24701394.2017.1331347.

3. Rajender S, Rahul P, Mahdi AA. Mitochondria, spermatogenesis and male infertility. Mitochondrion. 2010. https://doi.org/10.1016/ j.mito.2010.05.015.

4. Nakada K, Sato A, Yoshida K, Morita T, Tanaka H, Inoue SI, et al. Mitochondria-related male infertility. Proc Natl Acad Sci U S A. 2006;103:15148-53. https://doi.org/10.1073/pnas.0604641103.

5. Darley-Usmar V. The powerhouse takes control of the cell; the role of mitochondria in signal transduction. Free Radic Biol Med. 2004. https://doi.org/10.1016/j.freeradbiomed.2004.05.026. 
6. Shamsi MB, et al. Mitochondrial DNA mutations in etiopathogenesis of male infertility. Indian J Urol. 2008. https:// doi.org/10.4103/0970-1591.40606.

7. Alexeyev M, Shokolenko I, Wilson G, LeDoux S. The maintenance of mitochondrial DNA integrity - critical analysis and update. Cold Spring Harb Perspect Biol. 2013.

8. Baklouti-Gargouri S, Ghorbel M, Ben Mahmoud A, MkaouarRebai E, Cherif M, Chakroun N, et al. Mitochondrial DNA mutations and polymorphisms in asthenospermic infertile men. Mol Biol Rep. 2013;40:4705-12. https://doi.org/10.1007/s11033-013-25667.

9. Rovio AT, Marchington DR, Donat S, Schuppe HC, Abel J, Fritsche E, et al. Mutations at the mitochondrial DNA polymerase (POLG) locus associated with male infertility. Nat Genet. 2001;29: 261-2. https://doi.org/10.1038/ng759.

10. Holyoake AJ, McHugh P, Wu M, O'Carroll S, Benny P, Sin IL, et al. High incidence of single nucleotide substitutions in the mitochondrial genome is associated with poor semen parameters in men. Int J Androl. 2001;24:175-82. https://doi.org/10.1046/j.1365-2605. 2001.00292.x.

11. Spiropoulos J, Turnbull DM, Chinnery PF. Can mitochondrial DNA mutations cause sperm dysfunction? Mol Hum Reprod. 2002;8:719-21. https://doi.org/10.1093/molehr/8.8.719.

12. Thangaraj K, Joshi MB, Reddy AG, Rasalkar AA, Singh L. Sperm mitochondrial mutations as a cause of low sperm motility. J Androl. 2003;24:388-92. https://doi.org/10.1002/j.1939-4640.2003. tb02687.x.

13. Y. L, et al. Mitochondrial DNA mutation exacerbates female reproductive aging via impairment of the $\mathrm{NADH} / \mathrm{NAD}(+)$ redox. Aging Cell. 2020;19(19):e13206. https://doi.org/10.1111/acel.13206.

14. Khan AUH, et al. Human leukemic cells performing oxidative phosphorylation (OXPHOS) generate an antioxidant response independently of reactive oxygen species (ROS) production. EBioMedicine. 2016. https://doi.org/10.1016/j.ebiom.2015.11.045.

15. Garrido N, Meseguer M, Simon C, Pellicer A, Remohi J. Prooxidative and anti-oxidative imbalance in human semen and its relation with male fertility. Asian J Androl. 2004;6(1):59-65

16. Bahrehmand Namaghi I, Vaziri H. Sperm mitochondrial DNA deletion in Iranian infertiles with asthenozoospermia. Andrologia. 2017;49. https://doi.org/10.1111/and.12627.

17. Kao SH, Chao HT, Wei YH. Multiple deletions of mitochondrial DNA are associated with the decline of motility and fertility of human spermatozoa. Mol Hum Reprod. 1998;4:657-66. https:// doi.org/10.1093/molehr/4.7.657.

18. Al Zoubi MS, et al. 4,977-bp human mitochondrial DNA deletion is associated with asthenozoospermic infertility in Jordan. Andrologia. 2020;52:e13379. https://doi.org/10.1111/and.13379.

19. Al Zoubi MS, et al. CAG repeats in the androgen receptor gene is associated with oligozoospermia and teratozoospermia in infertile men in Jordan. Andrologia. 2020;52:e13728. https://doi.org/10. 1111/and.13728.

20. John JCS, Sakkas D, Barratt CLR. A role for mitochondrial DNA and sperm survival. J Androl. 2000;21(2):189-199. https://www. onlinelibrary.wiley.com/doi/abs/10.1002/j.1939-4640.2000. tb02093.x.

21. De Kretser DM. Male infertility. Lancet. 1997. https://doi.org/10. 1016/S0140-6736(96)08341-9.

22. Ferlin A, Raicu F, Gatta V, Zuccarello D, Palka G, Foresta C. Male infertility: role of genetic background. Reprod BioMed Online. 2007. https://doi.org/10.1016/S1472-6483(10)60677-3.

23. S., Singh AR, Vrtel R, Vodicka R, Dhaifalah I, Konvalinka D. Genetic factors in male infertility and their implications. Int $J$ Hum Genet. 2006;6(2):163-9.
24. Seli E, Sakkas D. Spermatozoal nuclear determinants of reproductive outcome: implications for ART. Hum Reprod Update. 2005. https://doi.org/10.1093/humupd/dmi011.

25. Hargreave TB. Genetic basis of male fertility. Br Med Bull. 2000. https://doi.org/10.1258/0007142001903454.

26. Erasmuson T, Sin IL, Sin FYT. Absence of association of androgen receptor trinucleotide expansion and poor semen quality. Int $J$ Androl. 2003;26:46-51. https://doi.org/10.1046/j.1365-2605.2003. 00388.x.

27. Smeitink J, Van Den Heuvel L, DiMauro S. The genetics and pathology of oxidative phosphorylation. Nat Rev Genet. 2001. https:// doi.org/10.1038/35072063.

28. Sharma L, Lu J, Bai Y. Mitochondrial respiratory complex I: structure, function and implication in human diseases. Curr Med Chem. 2009;16:1266-77. https://doi.org/10.2174/092986709787846578.

29. Yagi T, Matsuno-Yagi A. The proton-translocating NADH-quinone oxidoreductase in the respiratory chain: the secret unlocked. Biochemistry. 2003. https://doi.org/10.1021/bi027158b.

30. Hirst J, Carroll J, Fearnley IM, Shannon RJ, Walker JE. The nuclear encoded subunits of complex I from bovine heart mitochondria. Biochim Biophys Acta Bioenerg. 2003. https://doi.org/10.1016/ S0005-2728(03)00059-8.

31. Valdivieso ÁG, Marcucci F, Taminelli G, Guerrico AG, Álvarez S, Teiber ML, et al. The expression of the mitochondrial gene MTND4 is downregulated in cystic fibrosis. Biochem Biophys Res Commun. 2007;356:805-9. https://doi.org/10.1016/j.bbrc.2007. 03.057.

32. D. Voet, J. Voet, and C. Pratt, Fundamentals of Biochemistry life at the molecular level. 2011.

33. Selvi Rani D, Vanniarajan A, Gupta NJ, Chakravarty B, Singh L, Thangaraj K. A novel missense mutation C11994T in the mitochondrial ND4 gene as a cause of low sperm motility in the Indian subcontinent. Fertil Steril. 2006;86:1783-5. https://doi.org/ 10.1016/j.fertnstert.2006.04.044.

34. Gurses C, Azakli H, Alptekin A, Cakiris A, Abaci N, Arikan M, et al. Mitochondrial DNA profiling via genomic analysis in mesial temporal lobe epilepsy patients with hippocampal sclerosis. Gene. 2014;538:323-7. https://doi.org/10.1016/j.gene.2014.01.030.

35. Wallace DC, et al. Mitochondrial DNA mutation associated with Leber's hereditary optic neuropathy. Science (80- ). 1988. https:// doi.org/10.1126/science.3201231.

36. Restrepo NA, Mitchell SL, Goodloe RJ, Murdock DG, Haines JL, Crawford DC. Mitochondrial variation and the risk of age-related macular degeneration across diverse populations. 2015. https://doi. org/10.1142/9789814644730 0024.

37. World Health Organisation, WHO Laboratory Manual for the Examination of Human Semen and Sperm-Cervical Mucus Interaction.5th edn, Publ. behalf WHO by Cambridge Univ. Press, 2010.

38. Dankowski T, Schröder T, Möller S, Yu X, Ellinghaus D, Bär F, et al. Male-specific association between MT-ND4 11719 A/G polymorphism and ulcerative colitis: a mitochondria-wide genetic association study. BMC Gastroenterol. 2016;16:118. https://doi.org/10. 1186/s12876-016-0509-1.

39. Wang L, Bamlet WR, de Andrade M, Boardman LA, Cunningham JM, Thibodeau SN, et al. Mitochondrial genetic polymorphisms and pancreatic cancer risk. Cancer Epidemiol Biomark Prev. 2007;16:1455-9. https://doi.org/10.1158/1055-9965.EPI-07-0119.

40. Gonçalves VF, Giamberardino SN, Crowley JJ, Vawter MP, Saxena R, Bulik CM, et al. Examining the role of common and rare mitochondrial variants in schizophrenia. PLoS One. 2018;13: e0191153. https://doi.org/10.1371/journal.pone.0191153. 
41. Earp MA, Brooks-Wilson A, Cook L, Le N. Inherited common variants in mitochondrial DNA and invasive serous epithelial ovarian cancer risk. BMC Res Notes. 2013;6(1):1-6. https://doi.org/10. 1186/1756-0500-6-425.

42. Deschauer M, Bamberg C, Claus D, Zierz S, Turnbull DM, Taylor RW. Late-onset encephalopathy associated with a C11777A mutation of mitochondrial DNA. Neurology. 2003;60:1357-9. https:// doi.org/10.1212/01.WNL.0000055869.99975.4B.

43. Y.E. Park and T. O. Kim, Sexual dysfunction and fertility problems in men with inflammatory bowel disease, World J Mens. Health, 2019, doi: https://doi.org/10.5534/WJMH.190007.

44. Srinivasan TN, Padmavati R. Fertility and schizophrenia: Evidence for increased fertility in the relatives of schizophrenic patients. Acta Psychiatr Scand. 1997;96:260-4. https://doi.org/10.1111/j.16000447.1997.tb10161.x.

45. Sauna ZE, Kimchi-Sarfaty C. Understanding the contribution of synonymous mutations to human disease. Nat Rev Genet. 2011. https://doi.org/10.1038/nrg3051.
46. Wang Y, Qiu C, Cui Q. A large-scale analysis of the relationship of synonymous SNPs changing microRNA regulation with functionality and disease. Int J Mol Sci. 2015;16:23545-55. https://doi.org/ 10.3390/ijms 161023545 .

47. Duan J, et al. Synonymous mutations in the human dopamine receptor D2 (DRD2) affect mRNA stability and synthesis of the receptor. Hum Mol Genet. 2003. https://doi.org/10.1093/hmg/ ddg055.

48. Tian M, Bao H, Martin FL, Zhang J, Liu L, Huang Q, et al. Association of DNA methylation and mitochondrial DNA copy number with human semen quality. Biol Reprod. 2014;91:101. https://doi.org/10.1095/biolreprod.114.122465.

49. Smith M, Spence MA, Flodman P. Nuclear and mitochondrial genome defects in autisms. Ann N Y Acad Sci. 2009. https://doi.org/ 10.1111/j.1749-6632.2008.03571.x.

Publisher's note Springer Nature remains neutral with regard to jurisdictional claims in published maps and institutional affiliations. 